\title{
Effects of hypothalamic leptin gene therapy on osteopetrosis in leptin-deficient mice
}

\author{
Kenneth A Philbrick', Stephen A Martin', Amy R Colagiovanni', Adam J Branscum², Russell T Turner1,3 \\ and Urszula T Iwaniec 1,3
}

1Skeletal Biology Laboratory, School of Biological and Population Health Sciences, Oregon State University, Corvallis, Oregon, USA 2Biostatistics Program, School of Biological and Population Health Sciences, Oregon State University, Corvallis, Oregon, USA

${ }^{3}$ Center for Healthy Aging Research, Oregon State University, Corvallis, Oregon, USA

Correspondence should be addressed to U T Iwaniec: urszula.iwaniec@oregonstate.edu

\section{Abstract}

Impaired resorption of cartilage matrix deposited during endochondral ossification is a defining feature of juvenile osteopetrosis. Growing, leptin-deficient ob/ob mice exhibit a mild form of osteopetrosis. However, the extent to which the disease is (1) self-limiting and (2) reversible by leptin treatment is unknown. We addressed the first question by performing histomorphometric analysis of femurs in rapidly growing (2-month-old), slowly growing (4-month-old) and skeletally mature (6-month-old) wild-type (WT) and ob/ob male mice. Absent by 6 months of age in WT mice, cartilage matrix persisted to varying extents in distal femur epiphysis, metaphysis and diaphysis in ob/ob mice, suggesting that the osteopetrotic phenotype is not entirely self-limiting. To address the second question, we employed hypothalamic recombinant adenoassociated virus ( $\mathrm{rAAV}$ ) gene therapy to restore leptin signaling in ob/ob mice. Twomonth-old mice were randomized to one of the three groups: (1) untreated control, (2) rAAV-Leptin or (3) control vector rAAV-green fluorescent protein and vectors injected intracerebroventricularly. Seven months later, rAAV-leptin-treated mice exhibited no cartilage in the metaphysis and greatly reduced cartilage in the epiphysis and diaphysis. At the cellular level, the reduction in cartilage was associated with increased bone turnover. These findings (1) support the concept that leptin is important for normal replacement of cartilage by bone, and (2) demonstrate that osteopetrosis in ob/ob mice is bone-compartment-specific and reversible by leptin at skeletal sites capable of undergoing robust bone turnover.

\author{
Key Words \\ - bone formation and \\ resorption \\ - cartilage \\ - histology \\ ob/ob \\ - osteoclast
}

\section{Introduction}

The appetite regulatory hormone leptin is produced by adipose tissue (Zhang et al. 1994), is circulated in levels proportional to total adiposity (Considine et al. 1996) and may act to couple skeletal metabolism to energy availability (Steppan et al. 2000, Gat-Yablonski et al. 2004, Hamrick 2004, Iwaniec et al. 2007, Turner et al. 2013, 2014). Long bones in leptin-deficient $o b / o b$ mice are shorter, biomechanically weaker and exhibit lower overall bone mass and greater marrow adiposity compared to wild-type (WT) mice (Steppan et al. 2000, Ealey et al. 2006, Iwaniec et al. 2007, Turner et al. 2014, Lindenmaier et al. 2016). However, differences in cancellous bone volume fraction between $o b / o b$ and WT mice vary depending upon skeletal site and age. Leptin 
treatment in leptin-deficient mice normalizes bone volume and microarchitecture (Iwaniec et al. 2007) by increasing bone formation (Steppan et al. 2000, Hamrick et al. 2005, Kalra et al. 2009, Bartell et al. 2011, Turner et al. 2013) and resorption (Bartell et al. 2011, Turner et al. 2013, 2014, Philbrick et al. 2015), and increasing longitudinal bone growth (Gat-Yablonski et al. 2004, Iwaniec et al. 2007, Turner et al. 2013, Philbrick et al. 2015). Leptin treatment also normalizes bone marrow adiposity by reducing marrow adipocyte number and size (Lindenmaier et al. 2016). Taken together, these findings indicate that leptin affects bone marrow adiposity and skeletal growth, maturation and turnover balance.

Calcified cartilage provides a structural template for growing long bones during endochondral ossification and is normally replaced by bone during skeletal maturation. However, long bones of leptin-deficient $o b /$ $o b$ mice retain cartilage within cortical and cancellous bone compartments into adulthood resulting in a mild osteopetrotic skeletal phenotype (Turner et al. 2013, 2014). Osteopetrosis is broadly characterized into two major subtypes: osteoclast-poor and osteoclast-rich (Sobacchi et al. 2013). Mutations and/or factors that inhibit osteoclast formation are responsible for osteoclastpoor osteopetrosis. In contrast, mutations or factors that reduce osteoclast activity but do not inhibit osteoclast formation are responsible for the osteoclast-rich form of the disease. Both forms of osteopetrosis result in reduced bone resorption (Unnanuntana et al. 2011, Arruda et al. 2016). Severe osteopetrosis is fatal, while mild forms, such as that noted in $o b / o b$ mice, result in decreased bone quality. Furthermore, some forms of osteopetrosis are self-limiting; abnormally high quantities of cartilage are initially present in bone during rapid growth but the cartilage is eventually replaced as skeletal growth slows with age (Cielinski \& Marks 1994). At present, it is unclear whether the mild osteopetrosis observed in growing $o b / o b$ mice is self-limiting.

Osteoclast perimeter in $o b / o b$ mice is equal to or greater than in WT mice (Hamrick et al. 2004, Philbrick et al. 2015, Turner et al. 2013, 2014). In contrast, serum levels of carboxy-terminal collagen crosslinks (CTx, a biochemical marker of global bone resorption) are generally much lower and fluorochrome label retention in bone (a histomorphometric index of local bone resorption) is higher in $o b / o b$ mice compared to WT mice, providing strong complementary evidence that leptin deficiency results in reduced bone resorption (Bartell et al. 2011, Turner et al. 2013, 2014). Theoretically, excessive bone formation could contribute to mild osteopetrosis.
However, bone formation is impaired by leptin deficiency (Bartell et al. 2011, Hamrick et al. 2005, Philbrick et al. 2017, Turner et al. 2013, 2014), indicating that lower osteoclastic activity is responsible for the condition in $o b /$ $o b$ mice.

Osteoclast-rich forms of osteopetrosis can be induced by loss of function mutations in genes coding for proteins such as protease cathepsin $\mathrm{K}$ or chloride transporter ClCN7 required for osteoclastic activity but not for osteoclast formation and survival (Del Fattore et al. 2008). Additionally, drugs that inhibit bone resorption, such as bisphosphonates, have been shown to induce osteoclastrich osteopetrosis in children (Whyte et al. 2003). The mechanism for leptin regulation of osteoclast activity is yet to be established but likely involves coordinated actions of the hormone on multiple genes that in concert regulate osteoclast activity. In support, gene profiling has established that leptin deficiency results in altered expression of several genes related to osteoclast differentiation and function (Turner et al. 2014).

In the present investigation, we queried the extent to which osteopetrosis in $o b / o b$ mice is (1) self-limiting and (2) reversible by leptin treatment. We addressed the first question by performing histomorphometric analysis of femurs in rapidly growing (2-month-old), slowly growing (4-month-old) and skeletally mature (6-month-old) WT and $o b / o b$ male mice. To address the second question, we employed hypothalamic recombinant adeno-associated virus (rAAV) gene therapy in 2-month-old $o b / o b$ mice to restore leptin signaling and evaluated the bone response 7 months later. rAAV gene therapy has been used as an experimental strategy for life-long restoration of leptin signaling in leptin-deficient $o b / o b$ mice (Iwaniec et al. 2007, 2009, Kalra et al. 2009).

\section{Materials and methods}

\section{Animals}

Male C57BL/6J (B6) mice and $o b / o b$ mice on a B6 genetic background were obtained from Jackson Laboratory. Mice were maintained in accordance with the NIH Guide for the Care and Use of Laboratory Animals and the experimental protocols were approved by the Institutional Animal Care and Use Committee. Mice were housed individually in a temperature $\left(22^{\circ} \mathrm{C}\right)$ and light-controlled (lights on 06:00-18:00 h) room. Food (standard mouse chow) and water were available ad libitum to all animals. 
Study 1: Effects of age and leptin status on bone and cartilage in femur

Study 1 was performed in WT and $o b / o b$ mice to determine the distribution of cartilage in femurs in animals killed at 2 ( $n=10$ /group), 4 ( $n=5 /$ group) and 6 ( $n=3-5 /$ group) months of age. Two-month-old mice are rapidly growing, while skeletal maturity is reached between 4 and 6 months of age.

\section{Study 2: Effect of hypothalamic leptin gene therapy on bone and cartilage in ob/ob mice}

Study 2 was performed in $o b / o b$ mice to determine if the osteopetrotic skeletal phenotype persists in aged mice and, if so, whether long-duration hypothalamic leptin gene therapy normalizes skeletal maturation. Twomonth-old $o b / o b$ mice were randomized into one of the three treatment groups: (1) untreated control $(n=7),(2)$ rAAV-Leptin (rAAV-Lep, $n=9$ ) or rAAV-GFP (control vector encoding green fluorescent protein, $n=7$ ). The mice were maintained for 7 months post-vector administration. The effects of treatment on hypothalamic leptin gene expression, food intake, body weight, circulating metabolic hormone levels, bone microarchitecture and bone marrow adiposity have been reported elsewhere (Boghossian et al. 2007, Iwaniec et al. 2007, Lindenmaier et al. 2016).

\section{Construction and packaging of recombinant adenovirus vectors (rAAV)}

rAAV-Lep and rAAV-GFP vectors were constructed and packaged as described (Beretta et al. 2002). In brief, the vector pTR-CBA-Ob EcoRI fragment of pCR-rOb containing rat leptin cDNA was subcloned into rAAV vector plasmid pAAV $\beta$ GEnh after deleting the EcoRI fragment carrying the $\beta$-glucoronidase cDNA sequence. The control vector, rAAV-GFP, was similarly constructed to encode the GFP gene.

\section{Vector administration}

For vector administration, the mice were anesthetized with sodium pentobarbital $(60 \mathrm{mg} / \mathrm{kg}$, i.p.), placed on a Kopf stereotaxic apparatus with mouse adapter for intracerebroventricular (i.c.v.) injection and injected i.c.v. with either rAAV-Lep $\left(9 \times 10^{7}\right.$ particles) or rAAVGFP $\left(9 \times 10^{7}\right.$ particles). This dose was shown to normalize body weight in ob/ob mice (Ueno et al. 2004, 2006). The coordinates employed for microinjector placement in the 3rd cerebroventricle were $0.3 \mathrm{~mm}$ posterior to bregma,
0.0 lateral to midline and $4.2 \mathrm{~mm}$ below the dura (Boghossian et al. 2006).

\section{Tissue collection and analyses}

Mice were anesthetized with either isoflurane delivered in oxygen (Study 1) or sodium pentobarbital $(60 \mathrm{mg} / \mathrm{kg}$; i.p.) (Study 2) and killed by exsanguination. Femora were excised, cleaned of soft tissue, placed in 10\% formalin for $24 \mathrm{~h}$ and stored in $70 \%$ ethanol until processing. Distal femora were prepared for histomorphometric evaluation as described (Iwaniec et al. 2008). In brief, undecalcified femora were dehydrated and embedded in modified methyl methacrylate. Frontal sections, $4 \mu \mathrm{m}$ thick, were cut with a vertical bed microtome (Leica 2065) and affixed to gel-coated slides. One slide was stained for tartrate-resistant acid phosphatase and counter-stained with toluidine blue $(\mathrm{pH} 2.5)$ to identify osteoclasts and cartilage matrix, respectively. Cartilage matrix was identified by metachromatic staining of proteoglycans and glycosaminoglycans. A second slide was stained using the Von Kossa method and counter-stained with tetrachrome to identify osteoblasts and verify that linear growth had ceased in the femur in 6-month-old mice: the presence of bone bridging across the growth plate was used as an index of termination of longitudinal bone growth (Martin et al. 2003). Cartilage was measured in cancellous bone in the distal femur epiphysis and metaphysis and in cortical bone in the femoral diaphysis. The entire cancellous envelope was evaluated in the distal femur epiphysis. The region of interest in the distal femur metaphysis was located $0.25-0.85 \mathrm{~mm}$ proximal to the growth plate and $0.05 \mathrm{~mm}$ from cortical bone. Cortical bone was evaluated $4.4-5.6 \mathrm{~mm}$ proximal to the growth plate. Measurements of cartilage included metachromatic-stained area and chondrocyte area in the epiphysis, metaphysis and diaphysis. Measurements excluded growth plate and articular cartilage matrix. Osteoclast perimeter (osteoclast perimeter/bone perimeter, $\%$ ) and osteoblast perimeter (osteoblast perimeter/bone perimeter, \%) were also determined in the epiphysis. Measurements were performed at either 20 or $40 \times$ using the Osteomeasure Histomorphometry System (Osteometrics, Atlanta, GA, USA). Histomorphometric data are reported using standard 2-dimensional nomenclature (Dempster et al. 2013).

\section{Statistics}

Mean responses for bone and cartilage area fractions were compared between WT and $o b / o b$ mice at ages 2, 4 and 6 months using analysis of covariance (age modeled as a quantitative variable with a linear structure) or two-way 
analysis of variance (age modeled as a categorical variable). Goodness of fit assessment from scatterplots, Levene's test for homogeneity of variance, plots of residuals vs fitted values, normal quantile plots and Anderson-Darling tests of normality, and model selection from Akaike's information criterion, Bayesian information criterion and likelihood ratio tests were used to determine a linear model and evaluate contributions from interactions and main effects. Linear models containing different variance parameters across age and/or genotype groups were used to accommodate heterogeneous variance.

Mean responses for bone and cartilage fractions, and osteoblast and osteoclast perimeters were compared among the $o b / o b, o b / o b+$ rAAV-GFP and $o b / o b+$ rAAV-Lep groups using one-way analysis of variance, with $t$-tests used to make pairwise comparisons. The Kruskal-Wallis nonparametric test was used when only the normality assumption was violated, in which case the WilcoxonMann-Whitney test was used for two-group comparisons. A modified $F$ test was used when variances were distinct, with Welch's two-sample $t$-test used for two-group comparisons (Welch 1951).

The Benjamini and Hochberg (Benjamini \& Hochberg 1995) method for maintaining the false discovery rate at $5 \%$ was used to adjust for multiple comparisons. Differences were considered significant at $P \leq 0.05$. Trends are reported when $P<0.1$. All data are presented as mean \pm s.E. Data analysis was performed using $\mathrm{R}$ version 3.2.2.

\section{Results}

\section{Study 1: Effects of age and leptin status on bone and cartilage in femur}

The effects of age and leptin status on cancellous bone area fraction in the femoral epiphysis and metaphysis and on cartilage retention in the femoral epiphysis, metaphysis and diaphysis in WT and $o b / o b$ mice are shown in Fig. 1. Cancellous bone area fraction decreased with age in epiphysis (Fig. 1A) and metaphysis (Fig. 1C). The rate of decrease was not affected by genotype (interaction not significant). However, cancellous bone area fraction was lower in the epiphysis and tended to be lower $(P<0.1)$ in the metaphysis in $o b / o b$ mice compared to WT mice. Cartilage area fraction also decreased with age in the femoral epiphysis (Fig. 1B) and metaphysis (Fig. 1D), irrespective of genotype. Cartilage area fraction was higher in $o b / o b$ compared to WT mice at both sites. Negligible levels of cartilage matrix were observed in the diaphysis of WT mice (Fig. 1E). In contrast, cartilage matrix was present in the diaphysis of $o b / o b$ mice and significant changes with age were not detected.

Photomicrographs illustrating the distribution of cartilage matrix in the femoral epiphysis, metaphysis and diaphysis in representative 4-month-old WT and $o b / o b$ mice are shown in Fig. 2. By 4 months of age, little cartilage remained in femur epiphysis, metaphysis or diaphysis in WT mice. In contrast, cartilage is clearly evident at all 3 sites in $o b / o b$ mice. Bone bridging across the growth plate, indicative of cessation of longitudinal growth, was evident in 6-month-old WT and $o b / o b$ mice (Fig. 3) but not in 2-month-old or 4-month-old mice, verifying cessation of linear growth by 6 months of age in both genotypes.

\section{Study 2: Effect of hypothalamic leptin gene therapy} on bone and cartilage in ob/ob mice

The effects of long-duration hypothalamic leptin gene therapy on cancellous bone area fraction in the femoral epiphysis and metaphysis and cartilage retention in the femoral epiphysis, metaphysis and diaphysis in $o b / o b$ mice are shown in Fig. 4 . There was a tendency $(P<0.1)$ for cancellous bone area fraction to be higher in the epiphysis of rAAV-Lep-treated mice compared to untreated and rAAV-GFP-treated control mice (Fig. 4A). Differences in cancellous bone area fraction were not detected with treatment in the femoral metaphysis (Fig. 4C). Cartilage matrix was present in the epiphysis (Fig. 4B), metaphysis (Fig. 4D) and diaphysis (Fig. 4E) in untreated and rAAV-GFPtreated control mice. Treatment with rAAV-Lep resulted in lower cartilage area fraction in the epiphysis, metaphysis and diaphysis in comparison to untreated mice, lower cartilage area fraction in the metaphysis in comparison to rAAV-GFP mice and a tendency $(P<0.1)$ for lower cartilage area fraction in the epiphysis and diaphysis in comparison to rAAV-GFP mice. Significant differences between untreated and rAAV-GFP-treated mice were not detected for any of the endpoints evaluated. Photomicrographs illustrating the distribution of cartilage matrix in representative 9-monthold untreated, rAAV-GFP-treated and rAAV-Lep-treated $o b / o b$ mice are shown in Fig. 5.

The effects of long-duration hypothalamic leptin gene therapy on cellular indices of cancellous bone turnover in the femoral epiphysis are shown in Fig. 6. Osteoclast perimeter (Fig. 6A) and osteoblast perimeter (Fig. 6B) were higher in rAAV-Lep-treated mice compared to untreated and rAAV-GFP-treated mice. Significant differences in either osteoclast perimeter or osteoblast 


\section{Femoral Epiphysis}

A

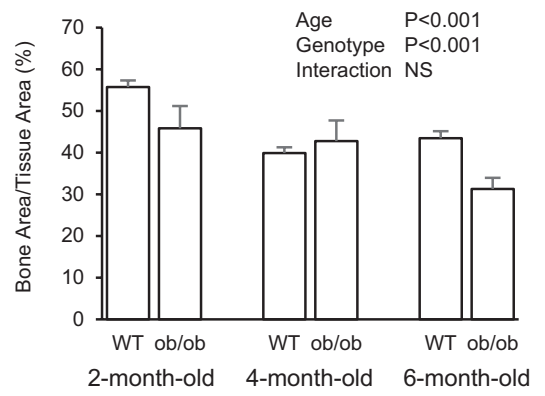

B

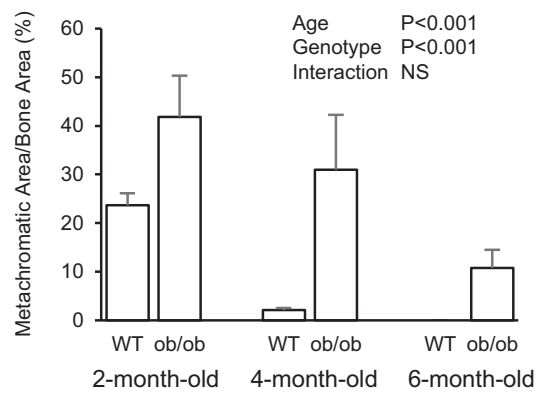

Femoral Metaphysis

C

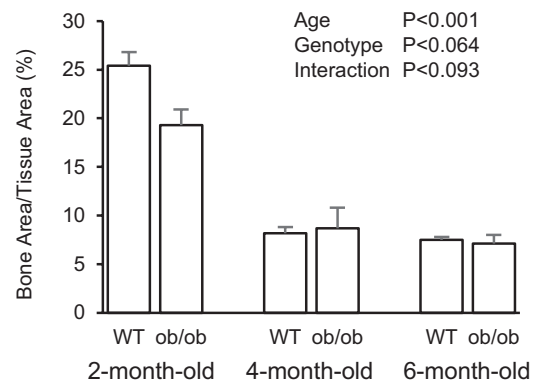

D Cartilage Area Fraction

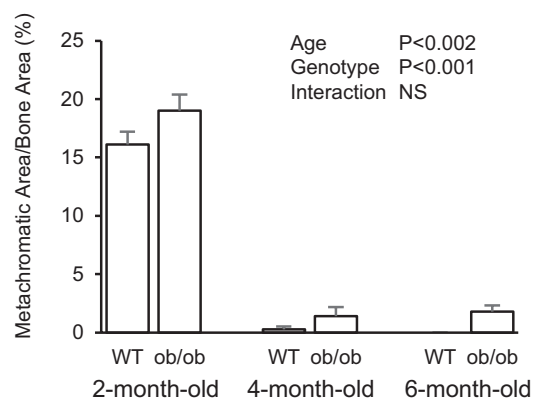

Femoral Diaphysis

E Cartilage Area Fraction

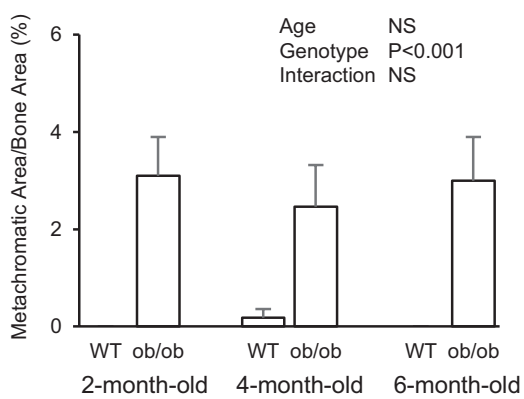

Figure 1

Effects of age and genotype on cancellous bone area fraction in distal femur epiphysis (A) and metaphysis (C) and cartilage retention in cancellous bone in distal femur epiphysis (B) and metaphysis (D) and in cortical bone in femur diaphysis (E) in 2-month-old, 4-month-old and 6-month-old male WT and leptin-deficient ob/ob mice. Data are mean \pm S.E.; $n=10 /$ group for 2-month-old mice, $n=5 /$ group for 4-month-old mice, $n=3$ and 5/group for 6-month-old WT and ob/ob mice, respectively. perimeter were not detected between untreated and rAAV-GFP-treated controls.

\section{Discussion}

Compared to WT mice, more extracellular cartilage matrix was present in cancellous compartments (metaphysis and epiphysis) of distal femur in $o b / o b$ mice. Cartilage matrix decreased with increasing age in both WT and $o b / o b$ mice but, in marked contrast to WT mice, cartilage continued to be present in the epiphysis and metaphysis in skeletally mature 6-month-old $o b / o b$ mice. Minimal or no cartilage matrix was found in the diaphysis of WT mice. In contrast, cartilage matrix was present in the diaphysis in $o b / o b$ mice, but unlike at cancellous sites did not decrease with age. Long-duration hypothalamic leptin gene therapy in growing $o b / o b$ mice reduced cartilage matrix at all skeletal sites evaluated. Lack of differences between rAAV-Lep and rAAV-GFP-treated mice provides strong evidence that increased leptin levels and not differences arising from the application 
Femoral Epiphysis
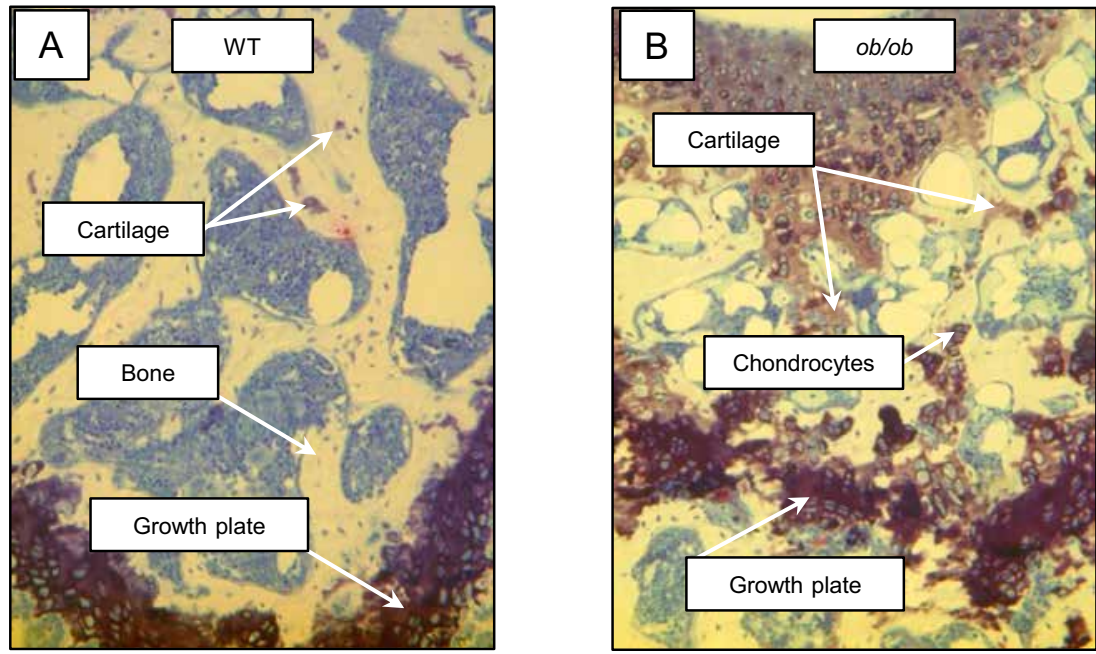

Femoral Metaphysis
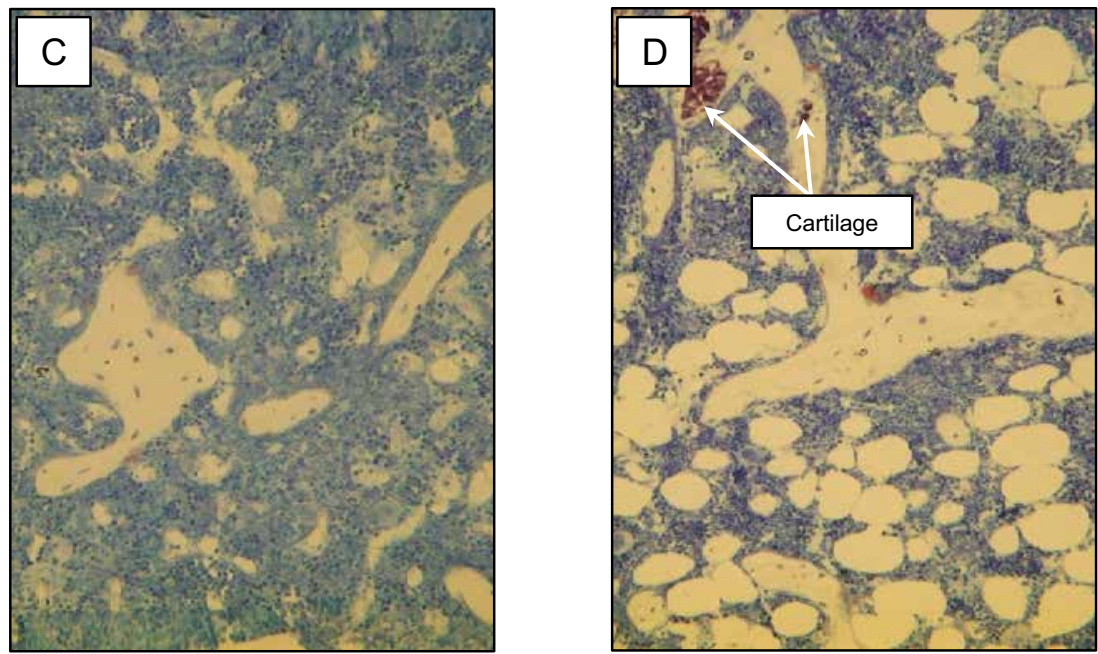

Femoral Diaphysis
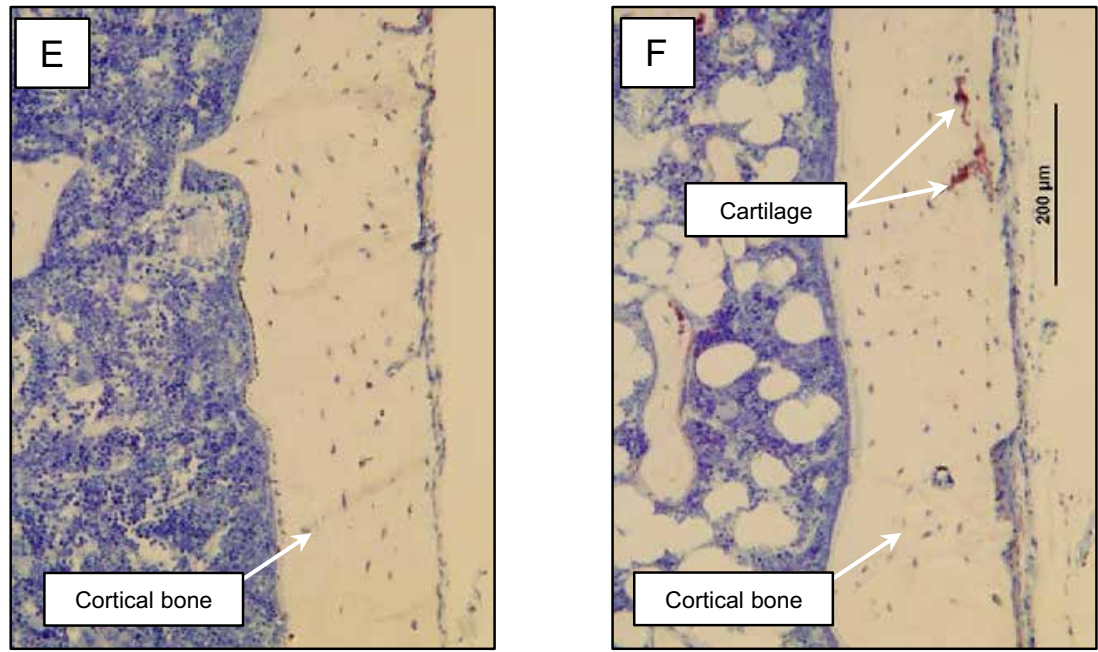

Figure 2

Photomicrographs of the distal femur epiphysis, metaphysis and diaphysis in representative 4-month-old male WT mice (A, C, E) and 4-monthold male leptin-deficient ob/ob mice (B, D, F). While cartilage matrix was rare in the epiphysis in WT mice (A), cartilage matrix and chondrocytes were readily visible in the epiphysis of ob/ob mice (B). Leptin-deficient $o b / o b$ mice also exhibited a highly disorganized growth plate architecture,

characterized by irregular margins and width (B). Cartilage was rare in the metaphysis and diaphysis of WT mice ( $C$ and $E$, respectively), but present at both sites in ob/ob mice ( $D$ and F). 

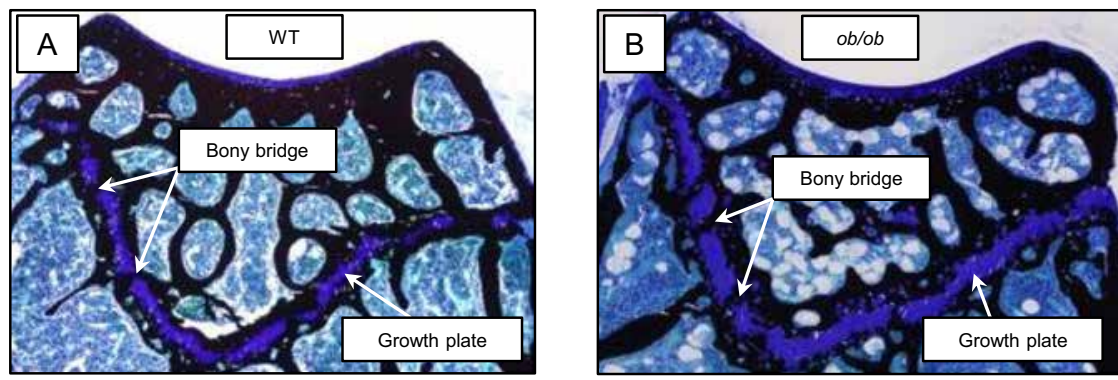

Figure 3

Photomicrographs of growth plate in distal femur in representative 6-month-old male WT (A) and 6-month-old male leptin-deficient ob/ob mouse (B). The bony bridges are indicative of cessation of longitudinal growth.

of gene therapy were responsible for the skeletal changes observed. At the cellular level, the reduction in cartilage in the epiphysis in rAAV-Lep-treated $o b / o b$ mice was associated with increased bone turnover (increased osteoblast and osteoclast perimeters).

Bone resorption is reduced in leptin-deficient $o b /$ $o b$ mice and leptin receptor-deficient $d b / d b$ mice due to impaired osteoclast function (Turner et al. 2013, 2014). Bone formation is also reduced in leptin-signaling-deficient mice due to reduced osteoblast-lined bone perimeter and reduced osteoblast activity (Turner et al. 2013). We hypothesized that the resulting reduction in turnover of primary spongiosa was the primary cause for prolonged retention of cartilage within the skeleton in $o b / o b$ mice (Turner et al. 2013, 2014). This hypothesis is supported by the current study. The slower matrix turnover in the epiphysis compared to metaphysis was positively associated with longer retention of cartilage matrix. In addition, a reduction in cartilage in the epiphysis following hypothalamic leptin gene therapy was associated with increased bone turnover. A similar relationship was previously observed for the metaphysis (Turner et al. 2013).

Osteoclasts play a key role in endochondral ossification. Osteoclasts are essential for (1) generation of primary spongiosa by directing vascular invasion into the growth plate and (2) replacement of mineralized cartilage matrix by bone to form secondary spongiosa (Odgren et al. 2016). Cartilage matrix is prevalent in distal femur in 2-month-old WT mice because the rate of cartilage matrix deposition during longitudinal growth exceeds the capacity of matrix turnover to replace cartilage with bone. However, longitudinal bone growth slows with age and in male B6 mice ceases between 4 and 6 months of age (Hoshi et al. 2004, Glatt et al. 2007). Cessation of linear bone growth in small rodents is due to the formation of bony bridges across growth plate cartilage precluding further elongation (Martin et al. 2003). In the current study, bony bridges were observed in the distal femur growth plate at 6 months of age in WT as well as ob/ob mice. The age range for longitudinal growth cessation corresponds to the disappearance of cartilage matrix from cancellous compartments.

Endochondral ossification is disrupted in long bones of $o b / o b$ mice, resulting in shorter bones, abnormal cancellous architecture and delayed replacement of cartilage matrix in primary spongiosa by bone matrix (Turner et al. 2013). In concordance with Kishida et al. (2005), we noted disorganized growth plate architecture in the leptin-deficient mice. Furthermore, prior studies demonstrated that thinning of the proliferative zone of the growth plate is associated with reduced longitudinal bone growth rate (Philbrick et al. 2015). Chondrocytes express the leptin receptor (Steppan et al. 2000, Kishida et al. 2005) and leptin was shown to exert positive actions affecting growth plate organization and growth plate expansion (Gat-Yablonski et al. 2004, Kishida et al. 2005). Hypertrophic chondrocytes contribute to programed removal of cartilage matrix by secretion of factors such as TNFSF11 (RANKL), MMP9 (matrix metallopeptidase 9), MMP13 (collagenase 3) and HMGB1 (high-mobility group protein 1) that mediate vascular invasion and are altered by leptin status (Koskinen et al. 2011, Mackie et al. 2011, Xiong et al. 2011, Schroeter et al. 2012). Thus, impaired chondrocyte function may contribute to the defect in osteoclast activity in $o b / o b$ mice.

Cortical bone in the femoral diaphysis develops by secondary intramembranous ossification. The presence of cartilage within the diaphysis of $o b / o b$ mice represents a pathological condition likely contributing to the lower biomechanical strength reported in $o b / o b$ and $d b / d b$ mice (Tuukkanen et al. 2000, Ealey et al. 2006, Henriksen et al. 2011, Williams et al. 2011). Haversian (intracortical) bone remodeling is absent in mice. This may explain why cartilage matrix trapped in the distal femur diaphysis in $o b / o b$ mice did not decline in quantity as the mice aged.

Leptin deficiency results in hypogonadism, hyperphagia, insulin resistance and morbid obesity. These metabolic and endocrine abnormalities could 


\section{Femoral Epiphysis}

A

Bone Area Fraction

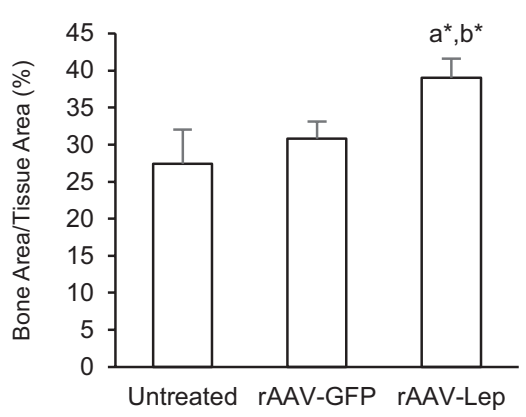

B Cartilage Area Fraction

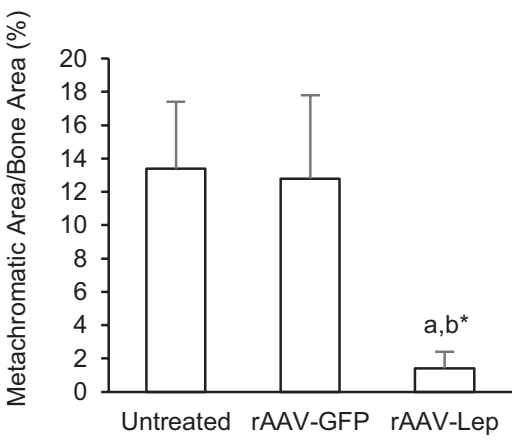

Femoral Metaphysis
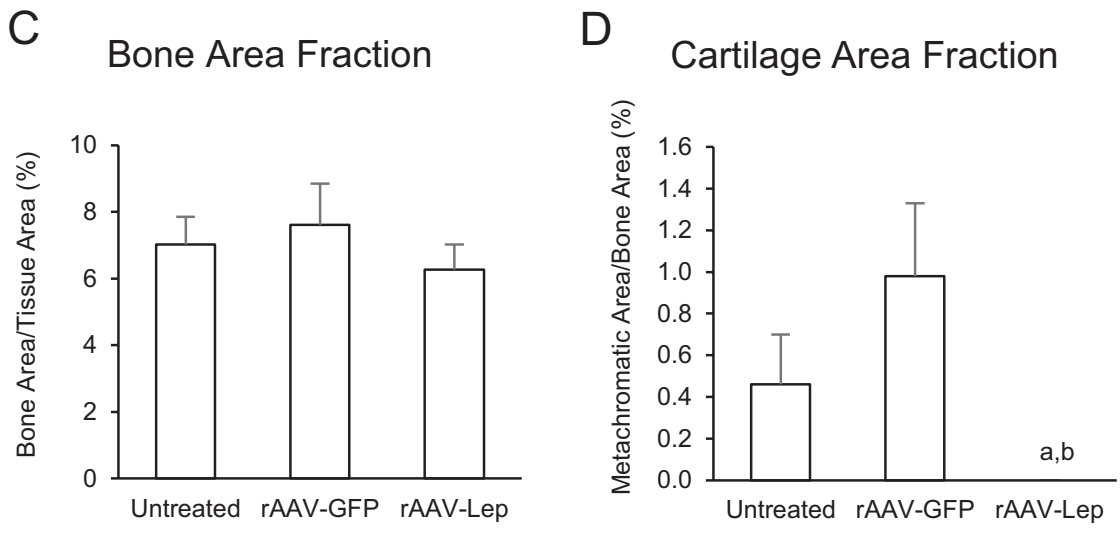

\section{Femoral Diaphysis}

E Cartilage Area Fraction

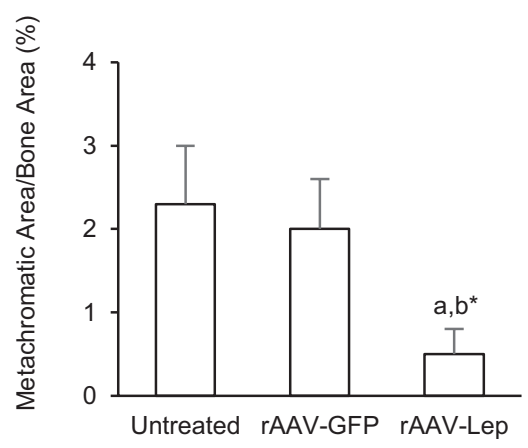

\section{Figure 4}

Effects of long-duration (7 months) hypothalamic leptin gene therapy (rAAV-Lep) on cancellous bone area fraction in distal femur epiphysis (A) and metaphysis (C) and cartilage retention in cancellous bone in distal femur epiphysis (B) and metaphysis (D) and in cortical bone in femur diaphysis (E) in male ob/ob mice. Data are mean \pm s.E.; $n=7-9 /$ group, adifferent from untreated, $P<0.05$, a* $P<0.1$; bdifferent rAAV-GFP, $P<0.05, \mathrm{~b} * P<0.1$. indirectly influence bone metabolism and thus contribute to skeletal defects observed in $o b / o b$ mice (Turner et al. 2017). Indeed, normalization of food intake, weight gain and blood glucose levels in $o b / o b$ mice actually exaggerated the abnormal skeletal phenotype (Turner et al. 2014), while estrogen receptor blockade did not impair the skeletal response of $o b / o b$ mice to leptin (Turner et al. 2017). Additionally, leptin exerted actions on the skeleton at levels having minimal impact on either energy metabolism or gonadal function (Philbrick et al. 2017). Taken together, these findings provide strong evidence that leptin acts on the skeleton to regulate bone growth and turnover. 
Femoral Epiphysis
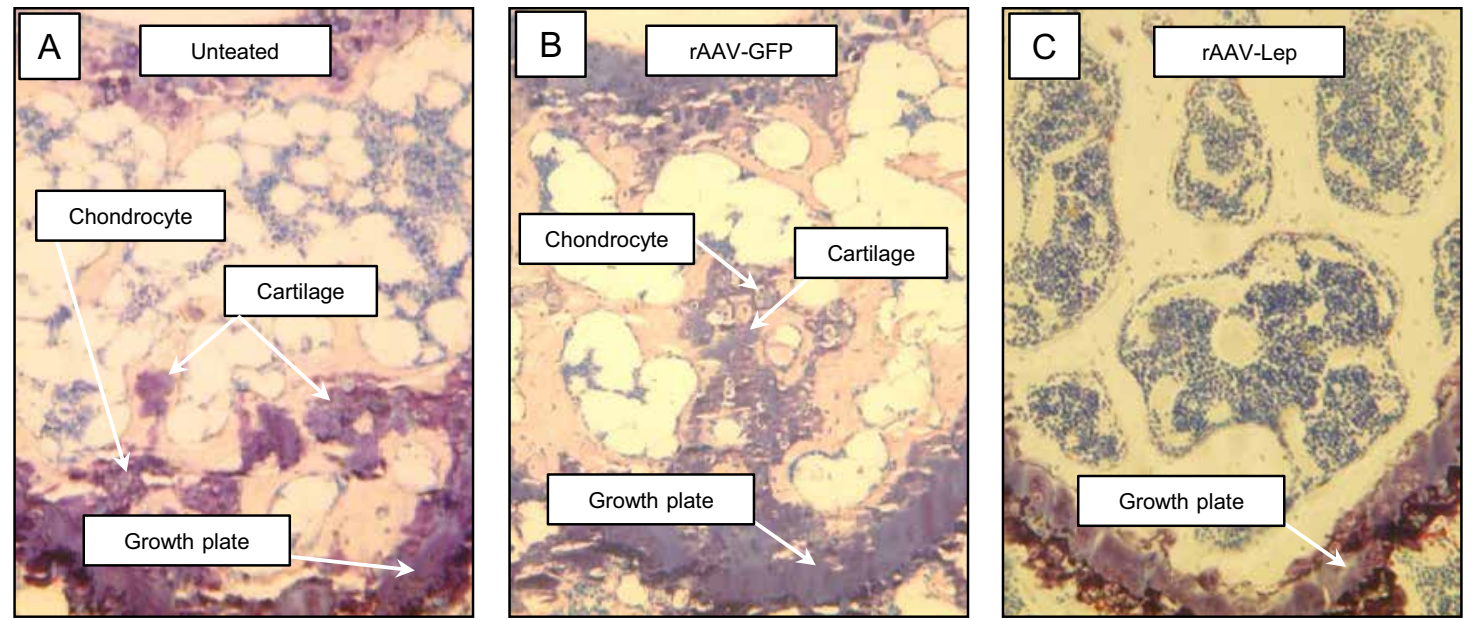

\section{Femoral Metaphysis}
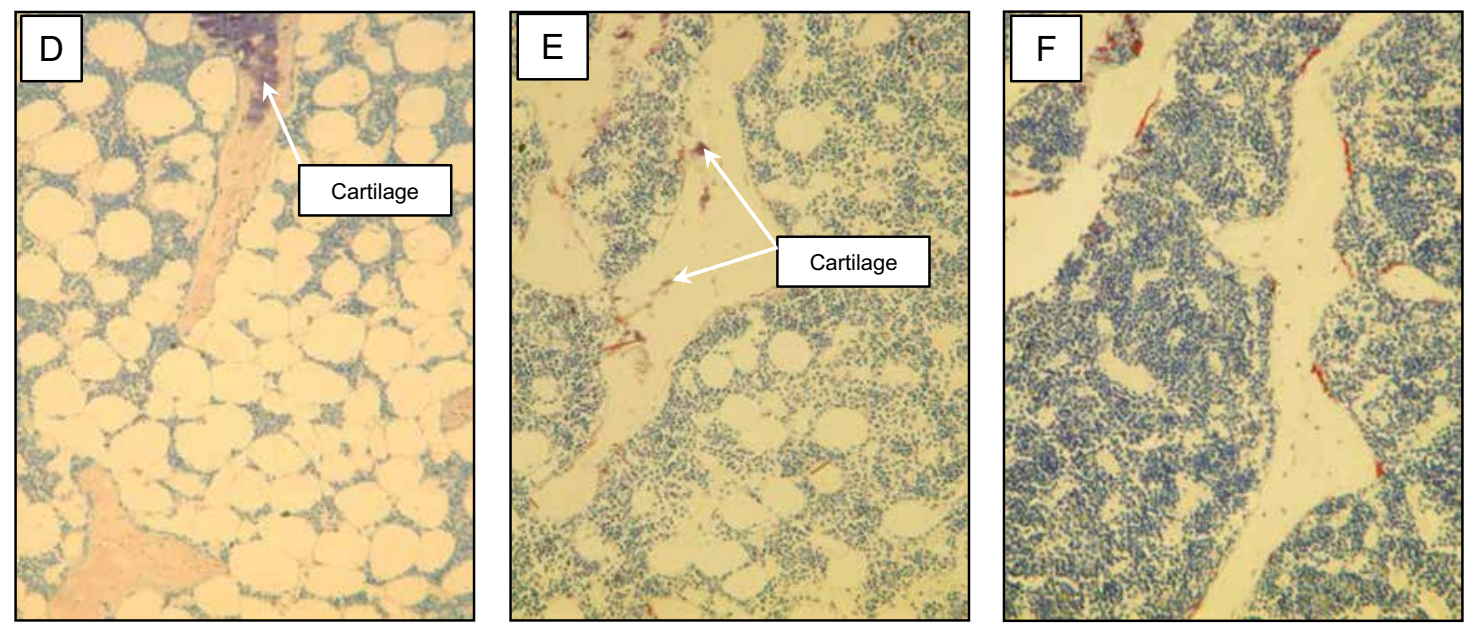

Femoral Diaphysis
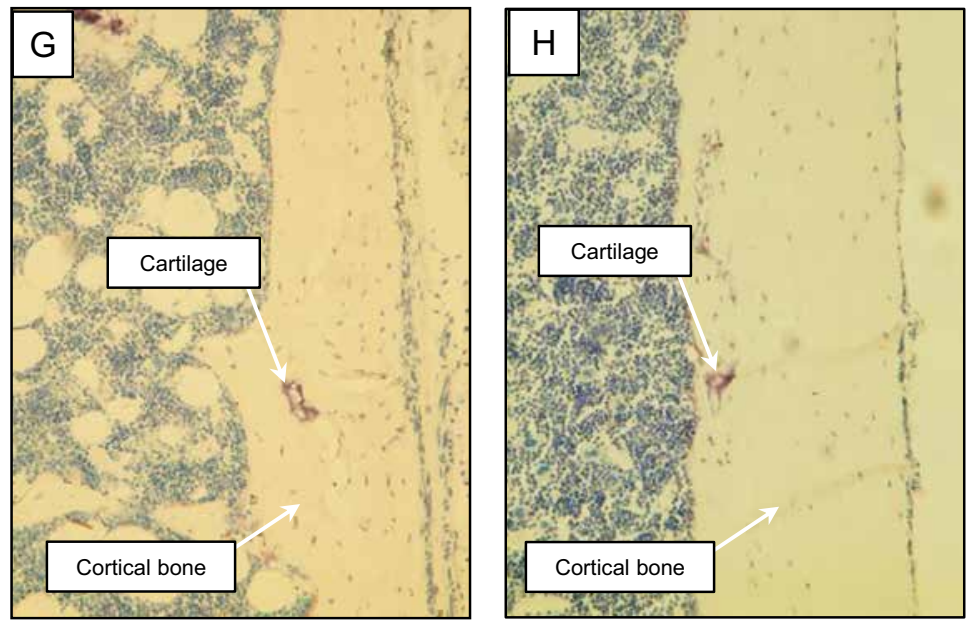

Figure 5

Photomicrographs of the distal femur epiphysis (A, B, C), metaphysis (D, E, F) and diaphysis (G, H, I) in representative 9-month-old untreated, rAAV-GFPtreated and rAAV-Lep-treated male ob/ob mice at 7 months post-vector administration. Note the presence of cartilage matrix in epiphysis, metaphysis and diaphysis of untreated mice ( $A, D$ and $G$, respectively) and rAAV-GFP-treated mice (B, E and $H$, respectively) and its absence in rAAV-Lep-treated mice (C, F and I, respectively).

$\begin{array}{lr}\text { http://joe.endocrinology-journals.org } & \text { ○ } 2018 \text { Society for Endocrinology } \\ \text { https://doi.org/10.1530/JOE-17-0524 } & \text { Published by Bioscientifica Ltd. } \\ \text { Printed in Great Britain }\end{array}$
Printed in Great Britain 
Femoral Epiphysis

A
Osteoclast Perimeter

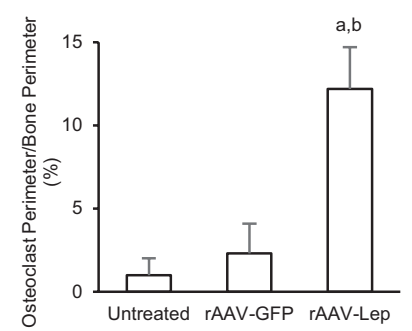

B Osteoblast Perimeter

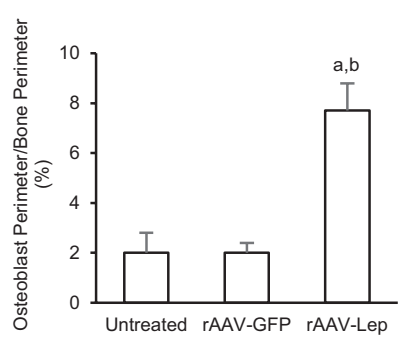

Figure 6

Effects of long-duration (7 months) hypothalamic leptin gene therapy on osteoclast perimeter (A) and osteoblast perimeter (B) in distal femur epiphysis in male ob/ob mice. Data are mean \pm s.E.; $n=7-9 /$ group; adifferent from untreated, $P<0.05$; ${ }^{b}$ different from rAAV-GFP, $P<0.05$.

Leptin deficiency also results in hypocalcemia (Ishida et al. 1988, Ozata et al. 1999), retinopathy (Kondo \& Kahn 2004), hearing loss (Lee et al. 2008) and tooth defects (Batt 1978, 1992). These abnormalities may be due, at least in part, to reduced osteoclast function. In support, defective bone resorption associated with osteopetrosis was shown to lead to impaired tooth eruption and impaired hearing and vision (Kocher \& Kasser 2003).

Hypothalamic leptin gene therapy normalized bone microarchitecture in growing $o b / o b$ mice by increasing bone growth and turnover (Iwaniec et al. 2007, Kalra et al. 2009, Turner et al. 2013). In the current study, hypothalamic leptin gene therapy promoted maturation of cancellous bone in distal femur. Infusion of leptin into the hypothalamus was initially reported to be antiosteogenic (Ducy et al. 2000) but subsequent studies failed to confirm this finding (Hamrick et al. 2005, Bartell et al. 2011). Specifically, the latter studies reported that leptin infusion into the hypothalamus of $o b / o b$ mice increased bone formation, bone mineral density and expression of osteogenic genes (Hamrick et al. 2005, Bartell et al. 2011). In support, we observed that increasing hypothalamic leptin levels by gene therapy increased histomorphometric, biochemical and gene expression markers of bone formation in $o b / o b$ mice (Turner et al. 2015). In addition to increased bone formation, hypothalamic leptin gene therapy increased osteoclast perimeter, an index of bone resorption, suggesting that leptin regulates bone turnover as well as bone accrual.

In summary, whereas cartilage matrix was absent within bone in 6-month-old WT mice, $o b / o b$ mice retained cartilage matrix to varying degrees at all anatomical sites evaluated. Long-duration hypothalamic rAAV-Lep gene therapy in $o b / o b$ mice increased bone turnover, resulting in substantial reduction in cartilage matrix within bone. Our findings (1) support the concept that leptin is important for normal replacement of cartilage by bone, and (2) demonstrate that osteopetrosis in $o b / o b$ mice is site-specific and reversible by leptin at skeletal sites capable of undergoing robust bone turnover.

\section{Declaration of interest}

The authors declare that there is no conflict of interest that could be perceived as prejudicing the impartiality of the research reported.

\section{Funding}

This work was supported by grants from the NIH (AR 054609), NASA (NNX12AL24) and USDA (38420-17804).

\section{Acknowledgements}

The authors thank Dr S P Kalra for designing Study 2 and for providing the bone specimens for analysis from this study and Dr S Boghossian for executing Study 2.

\section{References}

Arruda M, Coelho MC, Moraes AB, de Paula Paranhos-Neto F, Madeira M, Farias ML \& Vieira Neto L 2016 Bone mineral density and microarchitecture in patients with autosomal dominant osteopetrosis: a report of two cases. Journal of Bone and Mineral Research 31 657-662. (https://doi.org/10.1002/jbmr.2715)

Bartell SM, Rayalam S, Ambati S, Gaddam DR, Hartzell DL, Hamrick M, She JX, Della-Fera MA \& Baile CA 2011 Central (ICV) leptin injection increases bone formation, bone mineral density, muscle mass, serum IGF-1, and the expression of osteogenic genes in leptin-deficient ob/ ob mice. Journal of Bone and Mineral Research 26 1710-1720. (https:// doi.org/10.1002/jbmr.406)

Batt RA 1978 Abnormal dentition and decrease in body weight in the genetically obese mouse (genotype, ob/ob). International Journal of Obesity 2 457-462.

Batt RA 1992 Abnormal incisor teeth and body weight in the obese mouse (genotype ob/ob). International Journal of Obesity and Related Metabolic Disorders 16 29-34.

Benjamini Y \& Hochberg Y 1995 Controlling the false discovery rate: a practical and powerful approach to multiple testing. Journal of the Royal Statistical Society: Series B 57 289-300.

Beretta E, Dube MG, Kalra PS \& Kalra SP 2002 Long-term suppression of weight gain, adiposity, and serum insulin by central leptin gene therapy in prepubertal rats: effects on serum ghrelin and appetiteregulating genes. Pediatric Research 52 189-198. (https://doi. org/10.1203/00006450-200208000-00010)

Boghossian S, Dube MG, Torto R, Kalra PS \& Kalra SP 2006 Hypothalamic clamp on insulin release by leptin-transgene expression. Peptides $\mathbf{2 7}$ 3245-3254. (https://doi.org/10.1016/j.peptides.2006.07.022)

Boghossian S, Ueno N, Dube MG, Kalra P \& Kalra S 2007 Leptin gene transfer in the hypothalamus enhances longevity in adult monogenic mutant mice in the absence of circulating leptin. Neurobiology of Aging 28 1594-1604. (https://doi.org/10.1016/j. neurobiolaging.2006.08.010) 
Cielinski MJ \& Marks SC Jr 1994 Neonatal reductions in osteoclast number and function account for the transient nature of osteopetrosis in the rat mutation microphthalmia blanc (mib). Bone 15 707-715. (https://doi.org/10.1016/8756-3282(94)90321-2)

Considine RV, Sinha MK, Heiman ML, Kriauciunas A, Stephens TW, Nyce MR, Ohannesian JP, Marco CC, McKee LJ, Bauer TL, et al. 1996 Serum immunoreactive-leptin concentrations in normal-weight and obese humans. New England Journal of Medicine 334 292-295. (https:// doi.org/10.1056/NEJM199602013340503)

Del Fattore A, Cappariello A \& Teti A 2008 Genetics, pathogenesis and complications of osteopetrosis. Bone 42 19-29. (https://doi. org/10.1016/j.bone.2007.08.029)

Dempster DW, Compston JE, Drezner MK, Glorieux FH, Kanis JA, Malluche H, Meunier PJ, Ott SM, Recker RR \& Parfitt AM 2013 Standardized nomenclature, symbols, and units for bone histomorphometry: a 2012 update of the report of the ASBMR Histomorphometry Nomenclature Committee. Journal of Bone and Mineral Research 28 2-17. (https://doi.org/10.1002/jbmr.1805)

Ducy P, Amling M, Takeda S, Priemel M, Schilling AF, Beil FT, Shen J, Vinson C, Rueger JM \& Karsenty G 2000 Leptin inhibits bone formation through a hypothalamic relay: a central control of bone mass. Cell 100 197-207. (https://doi.org/10.1016/S00928674(00)81558-5)

Ealey KN, Fonseca D, Archer MC \& Ward WE 2006 Bone abnormalities in adolescent leptin-deficient mice. Regulatory Peptides 136 9-13. (https://doi.org/10.1016/j.regpep.2006.04.013)

Gat-Yablonski G, Ben-Ari T, Shtaif B, Potievsky O, Moran O, Eshet R, Maor G, Segev Y \& Phillip M 2004 Leptin reverses the inhibitory effect of caloric restriction on longitudinal growth. Endocrinology $\mathbf{1 4 5}$ 343-350. (https://doi.org/10.1210/en.2003-0910)

Glatt V, Canalis E, Stadmeyer L \& Bouxsein ML 2007 Age-related changes in trabecular architecture differ in female and male C57BL/6J mice. Journal of Bone and Mineral Research 22 1197-1207. (https://doi. org/10.1359/jbmr.070507)

Hamrick MW 2004 Leptin, bone mass, and the thrifty phenotype. Journa of Bone and Mineral Research 19 1607-1611. (https://doi.org/10.1359/ JBMR.040712)

Hamrick MW, Pennington C, Newton D, Xie D \& Isales C 2004 Leptin deficiency produces contrasting phenotypes in bones of the limb and spine. Bone 34 376-383. (https://doi.org/10.1016/j.bone.2003.11.020)

Hamrick MW, Della-Fera MA, Choi YH, Pennington C, Hartzell D \& Baile CA 2005 Leptin treatment induces loss of bone marrow adipocytes and increases bone formation in leptin-deficient ob/ob mice. Journal of Bone and Mineral Research 20 994-1001. (https://doi. org/10.1359/JBMR.050103)

Henriksen K, Flores C, Thomsen JS, Bruel AM, Thudium CS, NeutzskyWulff AV, Langenbach GE, Sims N, Askmyr M, Martin TJ, et al. 2011 Dissociation of bone resorption and bone formation in adult mice with a non-functional V-ATPase in osteoclasts leads to increased bone strength. PLOS ONE 6 e27482. (https://doi.org/10.1371/journal.pone.0027482)

Hoshi K, Ogata N, Shimoaka T, Terauchi Y, Kadowaki T, Kenmotsu S, Chung UI, Ozawa H, Nakamura K \& Kawaguchi H 2004 Deficiency of insulin receptor substrate-1 impairs skeletal growth through early closure of epiphyseal cartilage. Journal of Bone and Mineral Research 19 214-223. (https://doi.org/10.1359/JBMR.0301221)

Ishida H, Cunningham NS, Henry HL \& Norman AW 1988 The number of 1,25-dihydroxyvitamin D3 receptors is decreased in both intestine and kidney of genetically diabetic $\mathrm{db} / \mathrm{db}$ mice. Endocrinology $\mathbf{1 2 2}$ 2436-2443. (https://doi.org/10.1210/endo-122-6-2436)

Iwaniec UT, Boghossian S, Lapke PD, Turner RT \& Kalra SP 2007 Central leptin gene therapy corrects skeletal abnormalities in leptin-deficient ob/ob mice. Peptides 28 1012-1019. (https://doi.org/10.1016/j. peptides.2007.02.001)

Iwaniec UT, Wronski TJ \& Turner RT 2008 Histological analysis of bone. Methods in Molecular Biology 447 325-341. (https://doi. org/10.1007/978-1-59745-242-7_21)
Iwaniec UT, Dube MG, Boghossian S, Song H, Helferich WG, Turner RT \& Kalra SP 2009 Body mass influences cortical bone mass independent of leptin signaling. Bone 44 404-412. (https://doi.org/10.1016/j. bone.2008.10.058)

Kalra SP, Dube MG \& Iwaniec UT 2009 Leptin increases osteoblastspecific osteocalcin release through a hypothalamic relay. Peptides $\mathbf{3 0}$ 967-973. (https://doi.org/10.1016/j.peptides.2009.01.020)

Kishida Y, Hirao M, Tamai N, Nampei A, Fujimoto T, Nakase T, Shimizu N, Yoshikawa H \& Myoui A 2005 Leptin regulates chondrocyte differentiation and matrix maturation during endochondral ossification. Bone 37 607-621. (https://doi.org/10.1016/j.bone.2005.05.009)

Kocher MS \& Kasser JR 2003 Osteopetrosis. American Journal of Orthopedics 32 222-228.

Kondo T \& Kahn CR 2004 Altered insulin signaling in retinal tissue in diabetic states. Journal of Biological Chemistry 279 37997-38006. (https://doi.org/10.1074/jbc.M401339200)

Koskinen A, Vuolteenaho K, Nieminen R, Moilanen T \& Moilanen E 2011 Leptin enhances MMP-1, MMP-3 and MMP-13 production in human osteoarthritic cartilage and correlates with MMP-1 and MMP-3 in synovial fluid from OA patients. Clinical and Experimental Rheumatology 29 57-64.

Lee HS, Kim KR, Chung WH, Cho YS \& Hong SH 2008 Early sensorineural hearing loss in ob/ob mouse, an animal model of type 2 diabetes. Clinical and Experimental Otorhinolaryngology 1 211-216. (https://doi. org/10.3342/ceo.2008.1.4.211)

Lindenmaier LB, Philbrick KA, Branscum AJ, Kalra SP, Turner RT \& Iwaniec UT 2016 Hypothalamic leptin gene therapy reduces bone marrow adiposity in ob/ob mice fed regular and high-fat diets. Frontiers in Endocrinology 7 110. (https://doi.org/10.3389/ fendo.2016.00110)

Mackie EJ, Tatarczuch L \& Mirams M 2011 The skeleton: a multifunctional complex organ: the growth plate chondrocyte and endochondral ossification. Journal of Endocrinology 211 109-121. (https://doi.org/10.1530/JOE-11-0048)

Martin EA, Ritman EL \& Turner RT 2003 Time course of epiphyseal growth plate fusion in rat tibiae. Bone 32 261-267. (https://doi. org/10.1016/S8756-3282(02)00983-3)

Odgren PR, Witwicka H \& Reyes-Gutierrez P 2016 The cast of clasts: catabolism and vascular invasion during bone growth, repair, and disease by osteoclasts, chondroclasts, and septoclasts. Connective Tissue Research 57 161-174. (https://doi.org/10.3109/03008207.2016.1140752)

Ozata M, Ozdemir IC \& Licinio J 1999 Human leptin deficiency caused by a missense mutation: multiple endocrine defects, decreased sympathetic tone, and immune system dysfunction indicate new targets for leptin action, greater central than peripheral resistance to the effects of leptin, and spontaneous correction of leptin-mediated defects. Journal of Clinical Endocrinology and Metabolism 84 3686-3695. (https://doi.org/10.1210/jcem.84.10.5999)

Philbrick KA, Turner RT, Branscum AJ, Wong CP \& Iwaniec UT 2015 Paradoxical effects of partial leptin deficiency on bone in growing female mice. Anatomical Record 298 2018-2029. (https://doi. org/10.1002/ar.23267)

Philbrick KA, Wong CP, Branscum AJ, Turner RT \& Iwaniec UT 2017 Leptin stimulates bone formation in ob/ob mice at doses having minimal impact on energy metabolism. Journal of Endocrinology 232 461-474. (https://doi.org/10.1530/JOE-16-0484)

Schroeter MR, Stein S, Heida NM, Leifheit-Nestler M, Cheng IF, Gogiraju R, Christiansen H, Maier LS, Shah AM, Hasenfuss G, et al. 2012 Leptin promotes the mobilization of vascular progenitor cells and neovascularization by NOX2-mediated activation of MMP9. Cardiovascular Research 93 170-180. (https://doi.org/10.1093/cvr/ cvr275)

Sobacchi C, Schulz A, Coxon FP, Villa A \& Helfrich MH 2013 Osteopetrosis: genetics, treatment and new insights into osteoclast function. Nature Reviews Endocrinology 9 522-536. (https://doi. org/10.1038/nrendo.2013.137) 
Steppan CM, Crawford DT, Chidsey-Frink KL, Ke H \& Swick AG 2000 Leptin is a potent stimulator of bone growth in ob/ob mice. Regulatory Peptides 92 73-78. (https://doi.org/10.1016/S0167-0115(00)00152-X)

Turner RT, Kalra SP, Wong CP, Philbrick KA, Lindenmaier LB, Boghossian S \& Iwaniec UT 2013 Peripheral leptin regulates bone formation. Journal of Bone and Mineral Research 28 22-34. (https://doi. org/10.1002/jbmr.1734)

Turner RT, Philbrick KA, Wong CP, Olson DA, Branscum AJ \& Iwaniec UT 2014 Morbid obesity attenuates the skeletal abnormalities associated with leptin deficiency in mice. Journal of Endocrinology 223 M1-M15. (https://doi.org/10.1530/JOE-14-0224)

Turner RT, Dube M, Branscum AJ, Wong CP, Olson DA, Zhong X, Kweh MF, Larkin IV, Wronski TJ, Rosen CJ, et al. 2015 Hypothalamic leptin gene therapy reduces body weight without accelerating agerelated bone loss. Journal of Endocrinology 227 129-141. (https://doi. org/10.1530/JOE-15-0280)

Turner RT, Philbrick KA, Kuah AF, Branscum AJ \& Iwaniec UT 2017 Role of estrogen receptor signaling in skeletal response to leptin in female ob/ob mice. Journal of Endocrinology 233 357-367. (https://doi. org/10.1530/JOE-17-0103)

Tuukkanen J, Koivukangas A, Jamsa T, Sundquist K, Mackay CA \& Marks SC Jr 2000 Mineral density and bone strength are dissociated in long bones of rat osteopetrotic mutations. Journal of Bone and Mineral Research 15 1905-1911. (https://doi.org/10.1359/ jbmr.2000.15.10.1905)

Ueno N, Dube MG, Inui A, Kalra PS \& Kalra SP 2004 Leptin modulates orexigenic effects of ghrelin and attenuates adiponectin and insulin levels and selectively the dark-phase feeding as revealed by central leptin gene therapy. Endocrinology 145 4176-4184. (https://doi. org/10.1210/en.2004-0262)

Ueno N, Inui A, Kalra PS \& Kalra SP 2006 Leptin transgene expression in the hypothalamus enforces euglycemia in diabetic, insulin-deficient nonobese Akita mice and leptin-deficient obese ob/ob mice. Peptides 27 2332-2342. (https://doi.org/10.1016/j.peptides.2006.03.006)

Unnanuntana A, Rebolledo BJ, Khair MM, DiCarlo EF \& Lane JM 2011 Diseases affecting bone quality: beyond osteoporosis. Clinical Orthopaedics and Related Research 469 2194-2206. (https://doi. org/10.1007/s11999-010-1694-9)

Welch BL 1951 On the comparison of several mean values: an alternative approach. Biometrika 38 330-336. (https://doi.org/10.1093/ biomet/38.3-4.330)

Whyte MP, Wenkert D, Clements KL, McAlister WH \& Mumm S 2003 Bisphosphonate-induced osteopetrosis. New England Journal of Medicine 349 457-463. (https://doi.org/10.1056/NEJMoa023110)

Williams GA, Callon KE, Watson M, Costa JL, Ding Y, Dickinson M, Wang Y, Naot D, Reid IR \& Cornish J 2011 Skeletal phenotype of the leptin receptor-deficient $\mathrm{db} / \mathrm{db}$ mouse. Journal of Bone and Mineral Research 26 1698-1709. (https://doi.org/10.1002/jbmr.367)

Xiong J, Onal M, Jilka RL, Weinstein RS, Manolagas SC \& O’Brien CA 2011 Matrix-embedded cells control osteoclast formation. Nature Medicine 17 1235-1241. (https://doi.org/10.1038/nm.2448)

Zhang Y, Proenca R, Maffei M, Barone M, Leopold L \& Friedman JM 1994 Positional cloning of the mouse obese gene and its human homologue. Nature 372 425-432. (https://doi.org/10.1038/372425a0)

Received in final form 4 November 2017

Accepted 20 November 2017

Accepted Preprint published online 30 November 2017 